\title{
A Behavioral Perspective on Community Resilience during the COVID-19 Pandemic: The Case of Paraisópolis in São Paulo, Brazil
}

\author{
Fabio Bento * and Kalliu Carvalho Couto
}

Citation: Bento, F.; Couto, K.C.

A Behavioral Perspective on Community Resilience During the COVID-19 Pandemic: The Case of Paraisópolis in São Paulo, Brazil.

Sustainability 2021, 13, 1447. https:// doi.org/10.3390/su13031447

Academic Editor: Laurie Buys

Received: 7 December 2020

Accepted: 27 January 2021

Published: 30 January 2021

Publisher's Note: MDPI stays neutral with regard to jurisdictional claims in published maps and institutional affiliations.

Copyright: (c) 2021 by the authors. Licensee MDPI, Basel, Switzerland. This article is an open access article distributed under the terms and conditions of the Creative Commons Attribution (CC BY) license (https:// creativecommons.org/licenses/by/ $4.0 /)$.
Faculty of Health Sciences, Department of Behavioural Science, Oslo Metropolitan University, 0170 Oslo, Norway; kcouto@oslomet.no

* Correspondence: fabio.bento@oslomet.no
Abstract: The present article discusses the emergence and dynamics of community resilience by empirically investigating the case of the favela of Paraisópolis in São Paulo, Brazil. The emergence of innovative practices that initially contributed to significantly lower rates of COVID-19 infection and mortality when compared to the city average is described. The analytical framework combines two conceptual perspectives in the study of complex systems. First, resilience in socio-ecological systems highlights the adaptation processes characterized by an interplay of previous experience and emerging new knowledge. Second, the metacontingency framework describes the interplay between a cultural milieu, as a context for cultural practices; an aggregate product; and a selecting environment that embed the acquisition and continuity of interlocking behavioral contingencies. Research methods that combine elements of the descriptive analysis and an exploratory basic qualitative study are employed to understand how the community has self-organized during this period. The findings demonstrate how previous experience with social challenges facilitated self-organization and the emergence of innovative practices in the context of uncoordinated public health measures during the pandemic in Brazil. Furthermore, findings from interviews indicate the existence of positive feedback loops at the community level that facilitated the emergence of innovative practices. This study aims at contributing to the understanding of community resilience by identifying the geographic, psychological, and ecological factors (contextual variables) that facilitate responses to the pandemic.

Keywords: community resilience; complex systems; behavior analysis; metacontingencies; COVID-19

\section{Introduction}

Much of the debate about the effectiveness of the responses to the COVID-19 outbreak has focused on the effects of public policies adopted by different governments around the world. Such interventions have ranged from highly restrictive social distancing measures, closing most public spaces, to rather flexible ones [1]. However, from a complex system [2] perspective, it is also important to understand the decentralized emergence of practices and behaviors taking place at the community level. As claimed by Corburn et al. [3], there is a need to understand the dynamics of the robust social web of interactions and knowledge emerging from these. In this regard, Scott [4] provides a historical account of how large-scale policy initiatives have often failed in recognizing practical knowledge deriving from local interactions.

Research has demonstrated that low-income social groups are more exposed to risks brought by pandemics $[5,6]$. In slums and urban informal settlements, the short supply of basic needs, such as water drainage and waste collection, places the inhabitants in a particularly vulnerable position [3]. Furthermore, overcrowded spaces often make it challenging to control the spread of diseases that are transmitted by physical contact. However, the favela of Paraisópolis in São Paulo, Brazil has recently raised media attention as an example of a successful community response to the COVID-19 pandemic [7]. With 
an estimated population of 70,000 inhabitants, Ref. [8] Paraisópolis showed in May 2020 a mortality rate related to COVID-19 of 21.7 cases per 100 thousand inhabitants, which was, at that point, significantly lower than the entire city rate of 56.2 cases per 100 thousand inhabitants. A combination of different emergent practices originating from the favela has been implemented to fight the spread of the novel coronavirus.

As soon as members of the Paraisópolis community became aware of media reports about the COVID-19 outbreak, the residents' association began to mobilize its existent organized practices in order to cope with the possible effects of the pandemic on the community. This included crowdfunding to hire three ambulances, the use of local restaurants to distribute free meals, and grocery stores to provide basic hygiene products to families. Furthermore, the association established a decentralized network of 600 volunteers known as "street presidents," who were each responsible for monitoring the situation of about fifty households. The street presidents were also in charge of disseminating information about basic care, fighting the spread of fake news, and the early identification of potential cases. Over 240 residents were trained in first aid, and two public schools were used to isolate infected individuals. However, despite positive results in the first months of the pandemic, data from September 2020 indicated an increase in the mortality rate from 21.7 to 54 deaths per 100 thousand inhabitants [9]. This can be partially explained by the decrease in the amount of donations. Moreover, the reduction in social distancing measures in the city of São Paulo may be another reason as residents have to leave the favela to work.

The metacontingency approach has been successfully adopted to analyze several social complex systems, for example, the common community management of a lake [10] and an Acai berry extractives community [11]. While vaccines are still not widely available in most countries, public measures aiming to contain the spread of the virus still consist mainly of interventions on behaviors such as social distancing and the use of masks in public spaces. Therefore, a behavioral analytic approach to challenges brought by the pandemic is necessary $[12,13]$. Most behavior analytic studies addressing the COVID-19 pandemic have so far had an intrinsic conceptual character, highlighting the importance of metacontingencies. For instance, the study by Tibério et al. [14] discusses variables that may explain behaviors such as social distancing, wearing masks and washing hands. Camargo and Calixto suggest [15] non-coercive behavioral strategies to promote selfcontrol and social cooperation. Amorim et al. [16] bring a cultural/behavioral approach to discuss measures adopted by the state of São Paulo aiming at promoting social distancing. However, the literature review shows that, so far, no study has combined a behavioral analytic approach with concepts of complex science to address resilience and the emergence of new patterns of behavior at the community level during the COVID-19 pandemic.

The goal of this article is to present a descriptive analysis to assess the emergence of local knowledge and the practices in Paraisópolis as a response to the COVID-19 outbreak. A selectionist perspective is used to study the cultural phenomena by bridging complexity sciences and behavior analysis to analyze the Paraisópolis community as a socioecological [17,18] and self-organized system [2]. Complex systems are process-dependent organic-like entities characterized by feedback among multiple agents and scales, allowing system self-organization [19]. The first part of this article (Section 2) articulates a conceptual framework bridging the concepts of resilience from a complex systems [19] perspective and metacontingencies from behavior analysis to describe the practices within Paraisópolis before the pandemic outbreak. The metacontingency model [20-22] is then used to analyze the social dynamics that enable residents to coordinate their efforts to cope with a historical lack of governmental support and basic needs coverage. Thereafter, an interpretive analysis of how these practices shifted towards a community response to the COVID-19 crisis is presented. Paraisópolis' cultural milieu is then described (Section 4). The research methods (Section 4) combined elements of an interpretive analysis of documents and media coverage as well as a qualitative analysis of interviews with community members and leaders. Qualitative findings from interviews (Section 5) are discussed (Section 6) under the light of the concepts of resilience in socio-ecological systems [18], the interplay of different 
contextual factors (i.e., cultural milieu) [20], and how the residents organized their efforts and the outcomes. More specifically, resilience is investigated at the community level by highlighting the emergence and shift of cultural practices in Paraisópolis in response to the COVID-19 crisis (i.e., environmental perturbation).

\section{Community Resilience: Complex Systems and Metacontingencies}

The concept of community resilience has been a topic of research across various areas such as environmental science, engineering, social sciences and economics [23]. Concepts related to community resilience have evolved worldwide during the past thirty years as a response to different environmental disasters. However, there is at this point a lack of a general framework combining multidisciplinary aspects of community resilience [23]. Furthermore, as described by Koliou et al. [23], until recently there was little research combining complex interactions between the physical, social and economic dimensions of community resilience. There is at this stage a lack of common definition of community resilience, with the concept sometimes overlapping with robustness, fault-tolerance, flexibility, survivability, and agility [24]. A variety of studies have aimed at grasping the dynamics of community resilience from a social perspective [25-29]. Cohen et al. [25] have focused on the importance of information distributed by municipal authorities in the context of emergencies. They observed that this information flow is decisive for policies aiming to enhance community resilience. In a previous study, Cohen et al. [26] presented a community resilience measurement that focuses on six factors: leadership, collective efficacy, preparedness, place attachment, social trust and social relationships. Pfefferbaum et al. [27] compare different interventions aiming at enhancing community resilience and conclude by highlighting the importance of assessment, action planning and the recognition of the uniqueness of each community. Aldrich and Meyer [29] discuss the role of social capital and networks in the context of disaster recovery. They argue that although investments in infra-structure are important, there is a fundamental need to develop robust ties across individual and societal levels.

\subsection{Community Resilience and the COVID-19 Pandemic}

It is possible to observe the emergence of community resilience initiatives in many different social settings [30]. At the initial stage of the pandemic, such efforts usually aimed to support communities to adapt and maintain basic services in spite of the external challenges. The review study presented by Fransen et al. [30] focused on the adaptation aspect of community resilience. The next aspect, which would consist of learning processes and preparedness for future crises, is not approached in their study. Their study highlighted the importance of informal and formal bottom-up pathways in which the main actors are community members and local leaders. Many community resilience initiatives in the context of the COVID-19 pandemic emerge in low-income areas and often require tacit knowledge of specific target groups, previous skillsets, existing organizational capacity and webs of interaction. In another study, Wu et al. [31] looked at factors across social capital, economic capital, physical environment, demographic characteristics and institutional aspects influencing community resilience in Wuhan, China. The authors identify income level, vulnerability and built environment as the main factors associated with community resilience in this context.

So far, most studies about community resilience during the COVID-19 pandemic have focused on identify factors related to the emergence of community resilience. However, there is a need for studies focusing not only on the adaptation element of resilience, but also on the behavioral learning processes and lessons gained at the community level from a temporal and, therefore, evolutionary perspective. The framework of complex systems and metacontingencies articulated here brings a contribution in this direction. 


\subsection{Complex Systems and Metacontingencies}

Understanding complex and multilevel social phenomena, such as the dynamics of socio-ecological systems, often requires a multidisciplinary endeavor, integrating conceptual tools from different areas of knowledge. A complexity sciences interpretation will focus on how adaptive systems (unit of analysis) organize agents in an evolving structure, produce aggregate behavior, and anticipate environmental changes as a function of feedback. As described by Holland [32], complex adaptive systems share three main features: evolution, aggregate behavior, and anticipation. Evolution is usually observed not only by the agent's capacity to learn, but also by the adaptation taking place in the context of social interactions. This emergent property can be continuously observed beyond the context of emergencies or environmental perturbations. For example, residents of Paraisópolis have organized associations when faced with a lack of governmental investment in, among others, education, health, and sanitation. Thus, the residents' association is a social system of structures that emerged from, and were shaped by, the historical need to solve social issues. This social system may also be the basis for the adaptation to future challenges. Aggregate behavior has an intrinsically emerging character, meaning that it can only be fully understood by analyzing the parts in relation to each other. The aggregate behavior emerging from the organized efforts among the residents of Paraisópolis is the outcome for the community, such as employment creation and access to services within the community's geographical border. Anticipation means that agents develop rules that foresee the consequences of certain responses. At the system level, an emergent capacity to anticipate the consequences of patterns of behavior and the response to certain environmental changes is observed. This constant interplay between the agent's organization and reorganization as a function of environmental changes obeys a Darwinian-like evolutionary process. Interventions in complex systems typically aim to understand and modify aggregate behavior. However, complex systems are often nested in ever-changing environments and often pose perturbations to social systems. This requires a capacity to respond to unexpected events, and it highlights the necessity to understand resilience at the system level.

The discipline of behavior analysis has traditionally investigated the evolutionary continuity in how organisms (unity of analysis) discriminate environmental cues and change behavior as a function of consequences [33]. This functional relationship between classes of behavior and environmental changes is described as a contingency of reinforcement [34]. Later, efforts in behavior analysis have aimed to describe social systems from a selectionist perspective [21]. Glenn [35] presented the first formal behavior analytic operationalization of interactions among organisms and their outcomes as a unity of analysis. She proposes the metacontingency concept, which describes the functional relation between interlocking behavioral contingencies (IBCs), their aggregate product, and a selecting environment. IBCs take place when the behavior of one organism serves as the context or as the consequence (i.e., feedback) of the behavior of others. Such coordinated responses have an aggregate product as an outcome. IBCs and their aggregate products are selected and maintained by a selecting environment. The concept of metacontingencies extends the functional terminology of behavior analysis to the cultural analysis of social systems.

The metacontingency concept has a parallel to Holland's [32] account of complex systems, in which IBCs and evolution describe the emergence of aggregate products. The first descriptions of metacontingencies did not account for the anticipation aspects of a system, as described by Holland [32]. However, Houmanfar et al.'s [20] introduction of cultural milieu completes the last link for the parallel between metacontingency and complex systems analysis. As in anticipation for Holland, the cultural milieu was referred to as the sets of conditions and beliefs that enable a social system to anticipate the possible outcomes of IBCs (evolution) and aggregate products (aggregate behavior).

The Paraisópolis cultural milieu is embedded within the city of São Paulo's overall cultural milieu. Different governmental levels (municipal, state, and federal) are responsible for providing basic services, such as health-care facilities, education, and sanitation. However, the historical lack of investment in such services from the city of São Paulo to the 
Paraisópolis community has created a context for self-organization among the residents in order to bridge these gaps. That is, the lack of basic services, unemployment, and capital flight and other cultural milieu features of the community was the context that enabled the residents' coordinated response (IBCs) in the form of a residents' association, a local community bistro, a seamstress association, and other cultural practices. Among the aggregate products of such cultural practices is the creation of employment within the community, entrepreneurship, and other services lacking in the community. A selecting environment will feedback IBCs and aggregate products, while selecting and maintaining best practices. The contingent relation between IBCs, aggregate products, and selecting environments may produce positive feedback loops and increase the reach and efficacy of the community's cultural practices [36]. Figure 1 illustrates the community of Paraisópolis' cultural milieu, the IBCs, and their aggregate products and selecting environment before the COVID-19 outbreak.

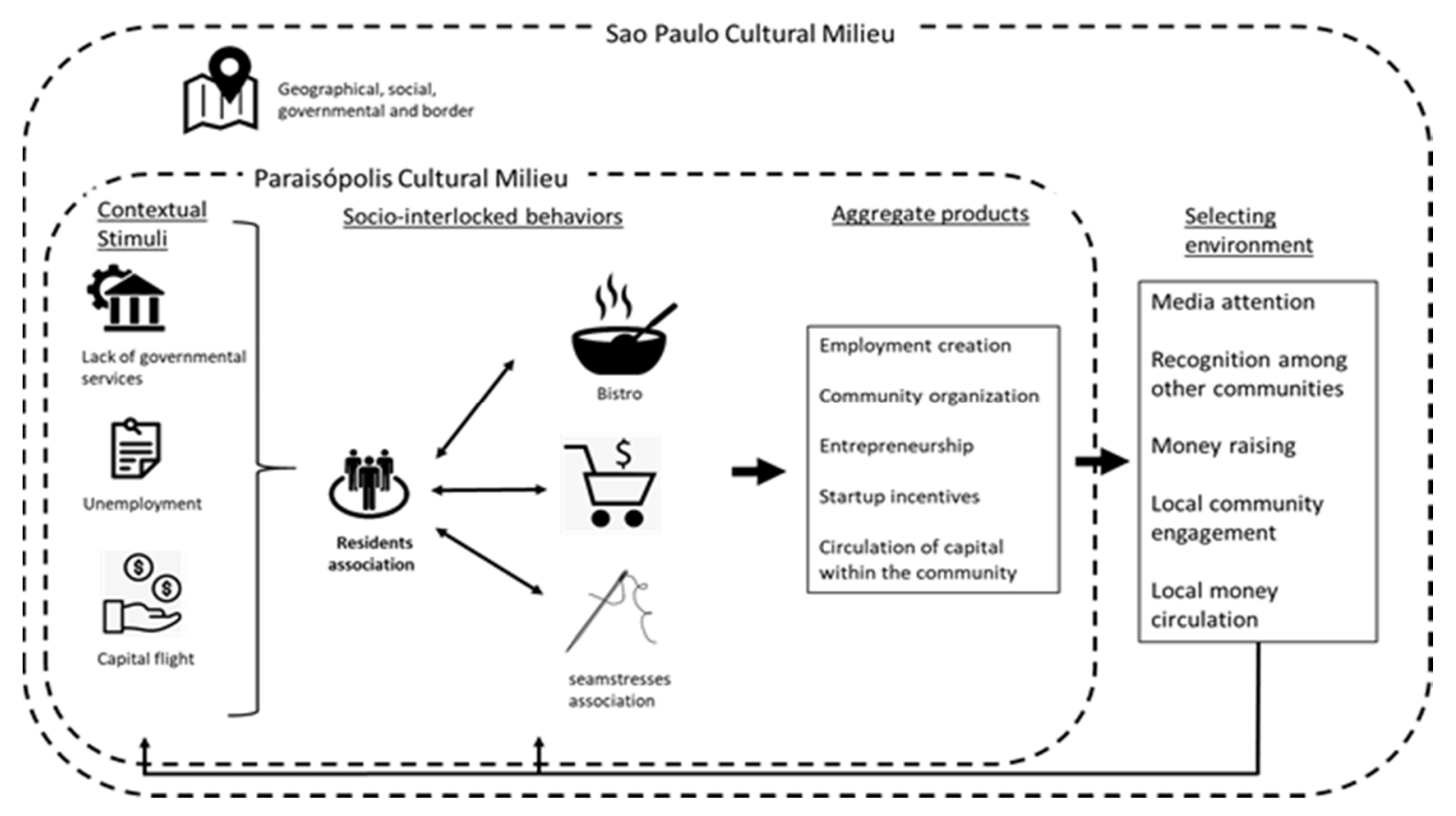

Figure 1. Paraisópolis' cultural milieu, selecting environment and aggregate products.

From a complexity perspective, Paraisópolis' emergent cultural practices are an "integrated system of ecosystems and human society with reciprocal feedback and interdependence" [37] (p. 3). Understanding these social dynamics' reciprocal interaction with past and present environmental variables may clarify the community response to the COVID-19 crisis. The system's capacity to "bounce back" from unexpected events and disturbances is usually defined as resilience [18]. Resilience involves an adaptive capacity to learn and reorganize structures and the emergence of new patterns of behavior. It is possible to discuss resilience at different levels (i.e., organism and system) and in different contexts. Likewise, there are indicators that successful practices at the community level are related to previous experiences with earlier pandemics [38] and efforts to tackle environmental crises [39]. In the case of Paraisópolis, the residents' association played an important role in articulating the emerging process and the collaboration with internal and external stakeholders. As presented by Folke [18], the resilience approach to socio-ecological systems highlights nonlinear dynamics, uncertainty, and the temporal interplay of periods of gradual and rapid change. Although much of the early research on socio-ecological systems focused on the ability to absorb perturbations and maintain functionality [40], the resilience approach emphasizes systems' capability for self-organization, learning, and renewal. More than the buffer capacity of robustness, resilience is related to the emerging self-organizing capacity 
of the system rather than the lack of organization or organization imposed by external factors [11]. In the case of the systems of human interaction, this usually highlights the importance of fostering collaborative learning networks and facilitating knowledge coproduction [41]. Resilience at the community level is often related to what Olsson et al. [42] define as an adaptive governance framework and collaboration among stakeholders at different social and ecological scales.

Adaptive governance means that formal processes co-exist with emergent webs of interaction, highlighting the need to understand ecosystem dynamics; develop management practices that integrate knowledge from different actors in order to interpret and respond to ecosystem feedback and continuously learn; build the adaptive capacity to deal with unexpected events; and sustain social networks in multi-level governance systems [43]. Cross-scale interaction is an important topic in the study of socio-ecological systems, which refers to a process occurring on one temporal or spatial scale interacting with a process at another scale [44]. The outcome may be the emergence of nonlinear dynamics and thresholds. Another important characteristic of complex systems is their path-dependency and the co-existence of multiple thresholds and regime shifts, meaning that there are multiple possibilities for qualitative shifts in system dynamics $[36,45,46]$. Multiple threshold and regime shifts at different scales co-exist, meaning that there are many possible future scenarios and responses to external disturbances. Bearing that in mind, it is important to move from the normative and prescriptive character of most literature on resilience in social systems [47]. Therefore, rather than identifying static properties of community resilience, a process-based perspective on resilience highlighting the underlying characteristics of resilience as a system capability is suggested [47]. In other words, resilience is seen as a meta-capability to anticipate, cope, and adapt in response to unexpected events rather than static characteristics and practices.

The next section describes the Paraisópolis community cultural milieu. Section 5 describes how the community has repurposed its cultural practices in order to adapt and bounce back from the challenges created by the COVID-19 crisis.

\section{Settings: Paraisópolis Cultural Milieu}

This section elaborates on a behavioral perspective of system resilience by looking at the contextual variables at different levels (i.e., the clusters within the community and city as a whole), which helps to explain how the cultural practices as IBCs deal with the challenges posed by the pandemic outbreak. At the level of the individuals, the interplay of three environmental variables composes the sets of events that influence behaviorbiological, anthropological, and psychological [48]. The biological environment consists of the basic premises of life, such as access to water, food, and shelter. The anthropological environment is created by humans and constitutes social contingency aspects at different levels, such as ethnic, community, and national. Moreover, the psychological environment may comprise both biological and anthropological objects assuming varying functional properties throughout the interaction with other individuals. As described by Sánchez et al. [22], human interactions in organized cultural groups can be looked at as systems of IBCs that are influenced by shared stimulus functions of events, objects, and persons. As the authors describe, stimulus functions are "properties of materials, resources, policies, rules, traditions, institutions, technological progress, art, other organized groups, competition, and individuals that are shared by multiple individuals" [22] (p. 301). Rather than being static configurations, sets of stimulus functions take place in dynamic networks of interactions and constitute aspects of the cultural milieu, which may change the patterns of aggregate behavior in a socio-ecological system over time. The evolutionary nature of the cultural milieu indicates that complex systems are characterized by an interplay of stability and change. As in metacontingencies, the individual capability to adapt to changes is influenced by norms or sets of contingencies that provide the context (anticipation) and consequences to their behavior in relation to others (IBCs). At the social system level, IBCs are under the stimuli control of environmental variables (anticipation), cueing the 
consequences to the production of different aggregate products. The effects or anticipation can be quite complex when large numbers of individuals or social systems interact. Thus, in metacontingencies, the aggregate product is largely dependent on contexts and will vary as a function of anticipation and the selecting environment. As described by Holland [32], anticipation also takes place at the aggregate level as complex systems develop internal models to anticipate the future and the expectation of future scenarios.

The present study looked at the cultural milieu of Paraisópolis and the contextual factors related to the community response to the COVID-19 pandemic. The analysis consisted of the presentation of descriptive findings related to the cultural milieu. The findings from the interviews highlight the characteristics, focus, and context of socio-ecological resilience in Paraisópolis. The next sub-sections present the ecological, geographical, and psychological boundaries of Paraisópolis and identify the cultural milieu factors.

\subsection{Ecological Boundary}

Ecological boundary is composed of the direct and indirect effects of the pandemic on different societal layers as an ecological perturbation that will ultimately affect the community of Paraisópolis. The first layer of effects takes place at the international community level, influencing the global economy and political systems. This layer does not have a tangible and immediate effect on Paraisópolis. The next ecological layer of perturbation takes place at the national level and concerns the effects of the first layer in addition to the effects of the pandemic itself on the pandemic in the Brazilian context. Since the first cases were detected in February 2020, the COVID-19 pandemic has been characterized by an exponential increase in the number of cases in Brazil. As of 30 November 2020, the country had the second highest number of deaths, second only to the United States [49]. Furthermore, the country had the world's tenth highest rate of deaths per 100 thousand inhabitants. São Paulo is the biggest metropole in Brazil, and the largest financial center in South America. It is also the home of multinational companies and international trade. In this way, the international economic effect of the pandemic outbreak has an amplified effect on the São Paulo economy. Thus, the São Paulo ecological boundary with respect to the pandemic is intertwined with the national and international variables. Although Paraisópolis is located adjacent to the prosperous neighborhood in the city of São Paulo, the community has historically been neglected in terms of basic services and public policies.

\subsection{Geographic Boundary}

Paraisópolis is the second largest favela in the city of São Paulo and the fifth largest in the country. The favela is located next to the wealthy district of Morumbi. In 2016, the community had the highest population density in the country with over 45 thousand inhabitants per square kilometer. In the same period, only $25 \%$ of the households had access to public water drainage, $60 \%$ had unregulated access to electricity, and half of the streets were not paved [50]. Population density, both in terms of community movement and inhabitants per household, is a geographical factor that negatively affects the transmission of infectious diseases. In addition, the lack of access to basic services exacerbates the health outcomes of a public health crisis. Figure 2 illustrates the contrast in living standards between Paraisópolis and Morumbi.

It is estimated that $79 \%$ of the employed population of the district of Vila Andrade, where Paraisópolis is located, works outside the boundaries of the district [52]. This indicates an intense movement of people in and out of the favela every day. Thus, the favela presents important features of complex systems, such as the exchange of resources with its surrounding environment and a dense web of interactions. This highlights the limitations of physical distancing measures taken by the residents' association in the context of uncoordinated public health measures implemented in the country and, more specifically, in the city of São Paulo. 


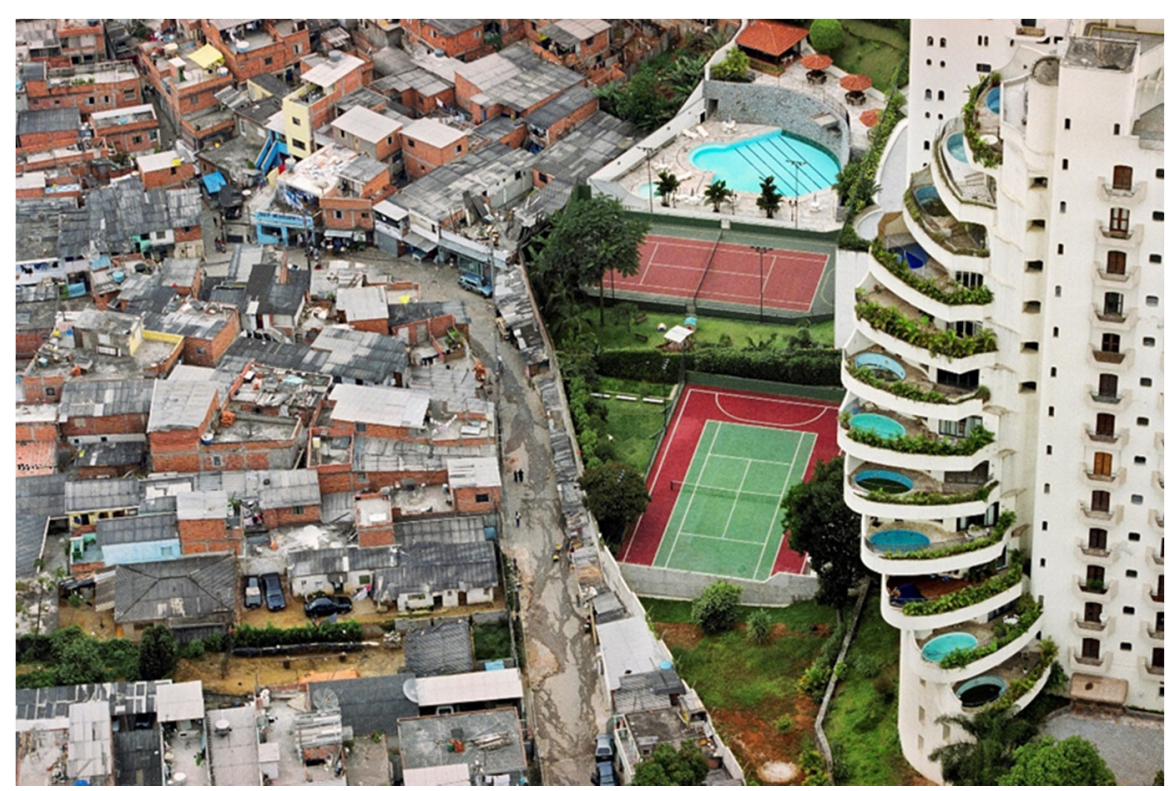

Figure 2. Physical boundary between Paraisópolis and the Morumbi neighborhood [51]. Republished with permission from the author.

\subsection{Psychological Boundary}

Each of the federative units (the twenty-six states and the Federal District) and municipalities in Brazil have administrative autonomy to implement their own policies. The level of adherence to recommendations from the World Health Organization (WHO) has varied across different governmental levels and regions. For instance, municipalities characterized by stronger support for the president, Jair Bolsonaro, have registered lower levels of social distancing and higher contamination and death rates [53,54]. It is at this point that a lack of coordination and even contradicting information among the different levels were observed. In April 2020, the federal government initiated a financial aid program providing monthly payments of BRL 600 (USD 104, as of November 2020) to low income families, small business owners, and unregistered workers harmed by the pandemic. The aid program, which was initially planned to last for three months, was later extended to the end of 2020. Although the federal government explicitly advised against social distancing measures, authorities at the state and municipal levels in São Paulo closed schools, prohibited non-essential public events, and recommended the use of masks in public spaces [16]. However, social distancing has been gradually alleviated since late May with the reopening of shops, restaurants, and parks. The São Paulo state government defined the Social Distancing Index (SDI) calculated from data regarding mobile phone movement to measure the outcomes of such policies [55]. Despite all the public health policies implemented by the state of São Paulo, the SDI of the state capital never reached the $70 \%$ rate which was regarded as necessary to contain the spread of the pandemic [16,56].

Paraisópolis has often been presented as an example of community organization in response to social problems. Community leaders have often advocated further urbanization efforts and the strengthening of the local economy as necessary developments to overcome the social stigma of poverty and to bring a change in terms of the psychological and social status of Paraisópolis from a favela to a regular neighborhood. Despite the uncoordinated efforts between the national, state, and municipal levels, the residents of the community were able to organize cultural practices to fight the spread of the virus. This was only possible thanks to the level of trust the residents had with each other and the social interaction that was in place before the COVID-19 outbreak occurred.

The analysis of the ecological, geographical, and psychological boundaries provides the context to discuss the web of interlocking metacontingencies at the community level. 


\subsection{Web of Interlocking Metacontingencies in Paraisópolis}

The community of Paraisópolis is among the areas in the city of São Paulo (cultural milieu; ecological, geographical, and psychological boundary) that suffer from a lack of governmental planning and services. These environmental variables served as contextual stimuli for organization among the residents, shaping their cultural practices, such as the creation of a residents' association, local services, and commerce initiatives. The aggregate products as a result of practices within the community were recognition from other communities, the creation of a local identity, and money circulation (Figure 1). Even though media outlets reported the international effects of the pandemic before the local outbreak, the city's response was delayed and uncoordinated. The low adherence of São Paulo residents to public policies also contributed to the high level of transmission. On the other hand, the previously established community organization in Paraisópolis, in face of the historical lack of investment in the community as well as demographic and geographic characteristics, started to reorganize in order to prepare for the effects of the crisis in the community.

Figure 3 shows the metacontingencies within the community in the context of the pandemic outbreak where São Paulo (cultural milieu) public policies were delayed, news about state infection rates was publicized, and there were disorganized public policies to fight the spread of the virus. Paraisópolis' residents' association anticipated that by the history of lack of services and community limitation, the virus could have a disastrous impact on the community. In this context, the cultural milieu for Paraisópolis acquired a new stimuli function (i.e., anticipation), which enabled the social system to reorganize and bounce back in order to face the challenges imposed by the pandemic (i.e., resilience).

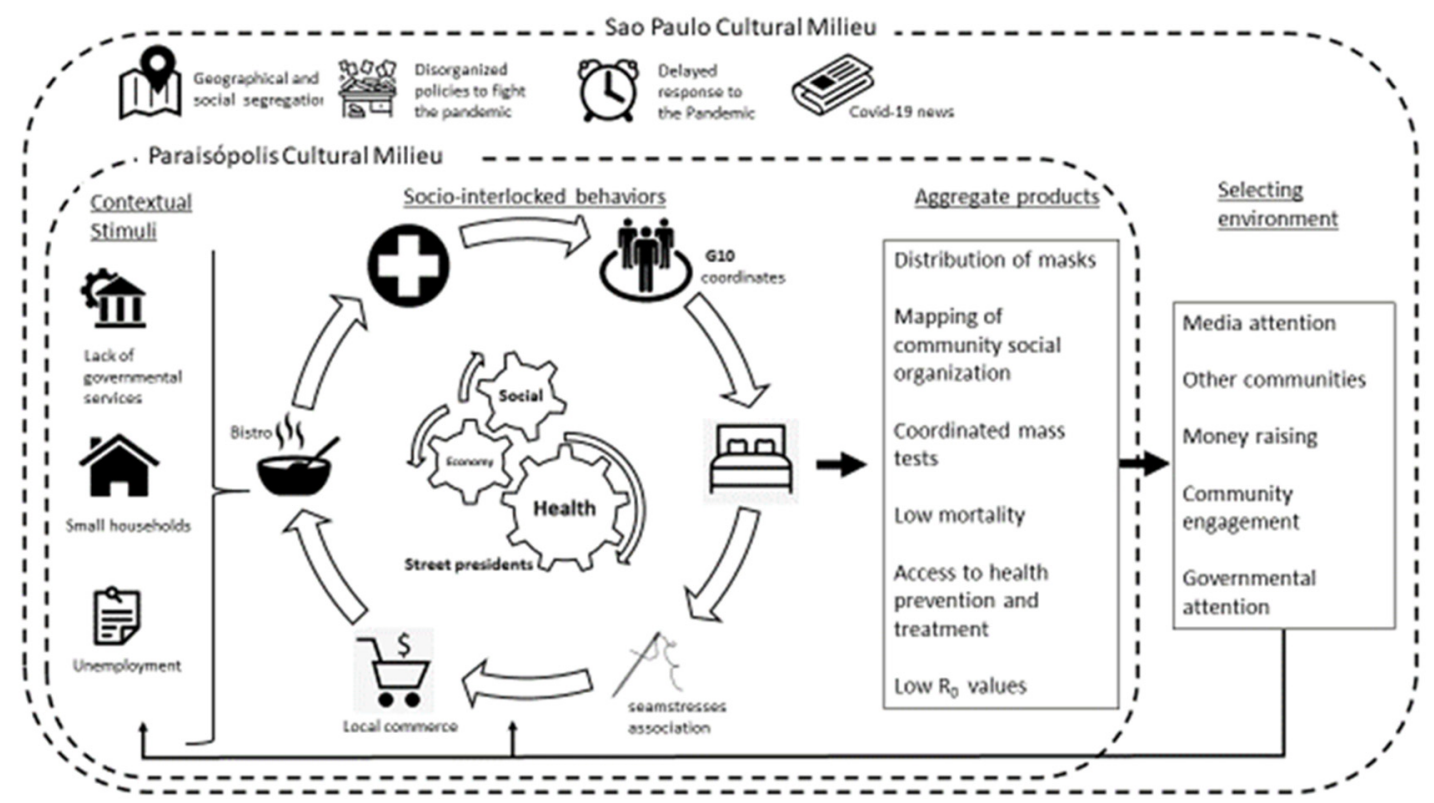

Figure 3. Web of socio-interlocking behavior and metacontingencies of the Paraisópolis community response to the COVID-19 outbreak.

\section{Methods}

As described by Amorim et al. [16], macro and metacontingencies have been the unit of analysis of several interpretive studies. The recognition of the complexity of the emergence of cultural phenomena and interlocked behavior change at a broad scale highlights the importance of interpretive studies focusing on metacontingencies. Thus, this study has two main empirical axes. First, it presents the qualitative accounts of participation in local practices gathered through interviews with four community members. In other words, the research methods present the elements of a basic qualitative study [57], which 
entails analyzing the descriptions of cultural practices from the participants' perspectives and providing the space for a discussion about learning and behavior change related to community resilience in Paraisópolis. The recognition of the complexity of real social settings characterized by an interplay of (often) unexpected factors permeates the choice of qualitative approach [58]. Second, a descriptive analysis [22] of objects and stimulus functions in the biological, anthropological, and psychological environments of Paraisópolis is presented. For that purpose, publicly available information through previous publications, research reports, and media material was used to descriptively present objects and stimulus functions associated to three environments and thereby present an overview of Paraisópolis.

\subsection{Data Gathering}

Conducting empirical research in the context of the pandemic turned out to be in itself a challenging task as it was difficult to visit the community in order to gather observational data of the practices and gain further contact with possible informants. The data gathering process can be divided in two stages: access to participants and conducting interviews.

\subsubsection{Access to the Community and Participants}

The researchers, who are located in a different country, initially contacted the residents' association in Paraisópolis, which then facilitated access to possible informants who were contacted by e-mail and phone messaging. The set of informants was composed of two individuals in formal leadership positions in the residents' association (two males) and two street presidents (two females). The lack of direct observational data typically gathered in ethnographic studies can be seen as a limitation of this study. On one hand, the data gathered through the qualitative interviews were triangulated with information available in other research reports and media coverage. The small number of participants does not offer statistical representativeness, and this can be regarded as a limitation of this study. Ideally speaking, it would have been preferable to interview more participants and conduct in loco observations. However, although it is not possible to claim statistical generalization of the experience of the community members, the data provide the opportunity to explore contextual factors linked to community resilience.

\subsubsection{Interviews}

The experiential and narrative accounts of two individuals in formal leadership positions in the residents' association and two street presidents offer insights on the evolution of complex systems such as contextuality and temporality [59]. The semi-structured interview guide (Appendix A) operationalized the concept of socio-ecological resilience, focusing on the following three topics and deriving concepts presented by Folke [18] (p. 259):

- Characteristics: interplay disturbance and reorganization, sustaining and developing;

- Focus: adaptive capacity, transformability, learning and innovation;

- Context: integrated systems feedback and cross-scale dynamic feedback.

The goal here was two-fold: to understand community resilience from a temporal perspective and identify the cultural milieu factors. The interview "plot" started with the participants' initial contact with the pandemic and awareness that it would reach the community. The interviewer then raised questions about the emergence of different practices and learning at different levels, the feedback levels, and the possibility for the retention of practices in a post-pandemic scenario.

\subsection{Analysis and Ethics}

The interviews were transcribed and analyzed with the help of NVivo, which is a software that supports the analysis of qualitative data. Interviews followed a theory-driven coding strategy [60], which means codes derived from the conceptualization of socioecological resilience, as suggested by Folke [18]. The data from interviews were initially categorized according to the three overall topics suggested by Folke [11]. This is the stage 
when the three overall topics of resilience were inserted in the project created on NVivo. The researchers then inserted codes within each of the three categories, further operationalizing the concept of socio-ecological resilience. The next analytical step consisted of coding the data according to the concepts within each category (interplay disturbance and reorganization, sustaining and developing, adaptive capacity, transformability, learning and innovation, integrated systems feedback, and cross-scale dynamic feedback). Figure 4 represents the categories and codes hierarchy as inserted on NVivo and used to analyze the qualitative data from interviews:



Figure 4. The analysis rationale with categories and codes (Extract from NVivo). Number of participants, and References = number of coded quotes from transcriptions.

The three descriptive tables in Section 5 illustrate this process by presenting quotes from interviews that are particularly representative of the qualitative findings within each of the overall categories and codes within these.

The information presented in the previous reports and media publications was mainly to grasp and identify the contextual factors of Paraisópolis and was also categorized from a theory-driven strategy embedded by three cultural milieu boundaries, as conceptualized by Kantor [48]. As described in the presentation of the results, different accounts of adaptive processes in the community matched the characteristics, focus, and context of resilience. The main ethical concern of this study consisted of protecting the anonymity of the participants. Real names and personal information that could identify the informants and other community members are not presented.

\section{Results}

The qualitative findings from interviews are described here.

\subsection{Characteristics: Interplay Disturbance and Reorganization, Sustaining and Developing}

The interviews provided different accounts of previous experiences with social challenges, interplay disturbance, and reorganization in the community. As described by the two community leaders, the initial perceptions of the pandemic and possible threats to the community arose in February with news of the pandemics in Europe and Asia and projections that the limited number of ventilators in the Brazilian health sector could lead to thousands of deaths in Brazil. At that time, the previous experiences with social problems and the different initiatives already implemented by the residents' association led to the initial responses to the pandemic and the reorganizations. The movement of the street presidents was initiated in response to a perceived need to create new leadership levels in the community and tighten contact with the residents. The residents' association is a member 
of G10, which is a nationwide association of the ten biggest favelas in Brazil through which emergent policies are disseminated to other communities. Table 1 depicts the accounts of four subcategories of findings and passages of interviews that were regarded as particularly representative.

Table 1. Interplay disturbance and reorganization, sustaining and developing.

\begin{tabular}{cl}
\hline Codes & \multicolumn{1}{c}{ Extracts From Interviews } \\
\hline Context & "Paraisópolis has always struggled with the absence of the state. If the rich population would \\
struggle with the restricted number of ventilators and possibly with the collapse of the health sector, \\
imagine people in our community who would not be able to follow the recommendations from World \\
Health Organization. We have large families living in small households" (Community leader A) \\
"We had never experienced a pandemic before, but we have eighty years of experience in demanding \\
public policies related to wastewater and urbanization. ( .. ) Paraisópolis was already seen as a \\
model in terms of implementation of social projects and social entrepreneurship. We already had \\
thirty-six social projects, including areas such as arts and sports" (Community leader B)
\end{tabular}

\subsection{Focus: Adaptive Capacity, Transformability, Learning and Innovation}

Although some of the initial responses to the pandemic involved redirecting the already existing initiatives into a new context, the creation of the street presidents' movement was innovative. The street presidents played an important role as interfaces between the residents and the redirected initiatives in the health, economical, and health fronts. The physical structures of two schools, which were not operating during the pandemic, were used to isolate infected individuals. The adaptive processes in the community involved both adjusting the already existing initiatives to cover the needs of the population in the context of the pandemic and the emergence of street presidents who facilitated communication between the population and the formal structure of the residents' association. Table 2 illustrates the findings related to the adaptive capacity of the community.

Table 2. Adaptive capacity, transformability, learning and innovation.

\begin{tabular}{cl}
\hline Codes & \multicolumn{1}{c}{ Extracts From Interview } \\
\hline “We created the movement of the street presidents and a web of solidarity and which the residents \\
help each other. Each president is responsible for fifty families making sure they stay home, \\
delivering donations and ordering medical help when necessary. We created three fronts: Health, \\
social, and medical" (Community leader A) \\
"In one of our meetings, someone mentioned a case when people self-organized in the context of \\
Spanish Flu. Then we discussed what we could do here in Paraisópolis and how we could use our \\
organization and the residents in the context of the pandemics ( ... ). It was very difficult in the \\
beginning ... this is cultural ... the people did not have the habit of helping each other. Now we \\
became clear that we need to help each other to cope with the situation" (Community leader B)
\end{tabular}




\subsection{Context: Integrated Systems Feedback, Cross-Scale Dynamic Feedbacks}

The interviews provided descriptions of the weekly general meetings organized by the residents' association, which provided an arena for communication between the community leaders and the street presidents. Although there were no accounts of formalized mechanisms for the results evaluation and monitoring, the weekly meetings were described in terms of spaces for cross-scale feedback. Information regarding the local interaction of the street presidents with the population was exchanged with information being presented by the community leaders regarding resource availability at the community level. Furthermore, all the participants expressed positive views of the street presidents' movement, and although the future seemed rather uncertain at the time, they highlighted the expectation that the initiative would be kept in the post-pandemic scenario. Table 3 shows the descriptions of practices monitoring and the expectations of the integration of new practices.

Table 3. Integrated systems feedback, cross-scale dynamic feedback.

\begin{tabular}{l} 
Codes \\
\hline "We have a group of coordinators responsible for monitoring the activity of street presidents in each \\
geographical area and listen to their demands. Then we have a weekly general meeting in which we \\
discuss problems identified in the community and solutions. The decision and communication \\
process happens in such meetings and through WhatsApp" (Community leader A) \\
"Community leader A provides us with information regarding donations and asks us how our work \\
is going" (Street president B) \\
"The organization of the street presidents will be kept and they will contribute to the creation of the \\
new Paraisópolis that we dream of, the favela transformed in a neighborhood ( ... ) We need to make \\
the government more sensitive to the need of new public policies. The whole society is talking about \\
a new normal post-pandemic, but the truth is that the favelas are still struggling to have their \\
'normal'. It is not normal that the ambulance doesn't drive here. It is not normal that people die over \\
a brook. It is not normal to have water shortages. It is not normal to have a rising unemployment. It \\
is not normal that people starve" (Community leader A) \\
"We will keep the street president in the post-pandemic. They will be able to keep their work without \\
us telling them what they have to do, monitoring their areas before we can come with our action" \\
(Community leader B) \\
"I don't know how it will be when the pandemic is gone but if it wasn't because of the street \\
presidents we wouldn't be able to do this incredible work. This can be kept. I think it will be useful in \\
the future" (Street president B)
\end{tabular}

The analysis of the descriptive findings identifies resilience concepts, as suggested by Folke [18], in the case of Paraisópolis. The findings suggest a reorientation of the existing practices and the emergence of new ones during adaptation to a major environmental disturbance. Although this adaptation process proved to be successful in the first two months of the pandemic, the increase in the infection and mortality rates observed in September 2020 raises questions regarding adaptations in the long term in the context of uncoordinated state policies in Brazil. There are important lessons to be taken from the descriptive analysis of Paraisópolis to research the contingencies of socio-ecological resilience and policy-making.

\section{Discussion}

Our analysis of Paraisópolis' response to the COVID-19 crisis highlights important characteristics of complex adaptive systems suggested by Holland [32]. First, a description of the evolutionary capacity of Paraisópolis' social system to adapt to environmental disturbances was presented. Second, the emergence of aggregate behavior from local interactions in the form of the reorientation of already existing practices and the development of street presidents was observed. Likewise, accounts from the interviews described the anticipation of the implications of the pandemic for the community and of individual behavior at the local level. The community response to the novel coronavirus pandemic showed a self-organization capability due to previous experience with social challenges 
and the emergence of a new web of interactions in the form of the experience of the street presidents. As with other cases of successful community responses [39], an interplay of knowledge gathered through previous experiences with the exploration of new possibilities was identified here. Thus, the resilience aspect of new practices involved a self-organizing character. This new organization showed important results in containing the effect of the spread of the virus in the initial stage of the pandemic in São Paulo. One may enquire if this response was the only possible effective response in that period. Bearing in mind that complex systems are path-dependent entities characterized by thresholds and multiple possible equilibria points, the emerging structure of the street presidents is one out of many possible emerging structures in this context. Thus, the resilience aspect of Paraisópolis does not consist of the movement of the street presidents per se; it consists of the community's capacity to generate new social structures in response to an environmental change. Previous experience may enhance the system's capacity to anticipate possible scenarios, but resilience lies in the self-organizing capacity to develop new structures within the same organization in response to an environmental perturbation.

By analyzing community resilience as a system capability, Duchek [47] highlighted the importance of feedback loops that either amplify emerging changes or restrain them [46]. In this regard, the previous existence of open channels for communication between the community leaders and the residents facilitated communication about challenges and the allocation of resources. Although there was no formal assessment of the street presidents' activity and the other initiatives, meetings at the residents' association provided the opportunity to monitor practices.

A metacongingency analysis will consider how international news about the pandemic was the first cultural milieu change signaling that a new social organization needed to be created to deal with a possible upcoming crisis. Such news served as cultural milieu as in the context of an historical lack of support from the state, the prospect of unemployment increase, and other issues related to the pandemic served as contextual stimuli for the community's response to the pandemic. The socio-interlocked behaviors were already existent within the community, such as the community bistro, the seamstress association, and the residents' association. Others were created to cope with the demands generated by the pandemic. The services created at the community level were overseen by the residents' association and were monitored and implemented with the help of street presidents. The association took measures to slow the spread of the infection. In response to the pandemic threat, the community association began to reorganize its practices in order to fight the effects of the virus on three fronts: economic, social, and health. This is interpreted from a complexity perspective as system anticipation and as the cultural milieu from a behavior analytic perspective. Among the aggregate products of socio-interlocked behaviors, there was the mapping and monitoring of the community's social organization, the monitoring of residents who contracted or were suspected to contract the disease, the wide distribution of meals for residents in need, and the production and distribution of masks. A selecting environment composed of media attention and access to financial resources fed back the metacontingency, making it more probable to persist over time. The functional relation between Paraisópolis' cultural milieu, including the ecological, geographical and psychological boundaries, the interlocking behaviors and practices, their aggregate product, and the receiving system can be understood as a metacontingency.

Public health policy may benefit from learning about resilience and the emergence of innovative responses at the community level. The analysis of the IBCs suggests a degree of internal cohesion and the acceptance of recommendations from the WHO, which is reflected in the aggregate product. However, the maintenance of such practices depends to a high extent on how they are received in the selecting environment. In this regard, public health measures can be seen as interventions in the selecting environment, which may contribute to the continuity of successful cultural practices. Public policies may constitute either positive feedback loops facilitating resilience at the community level or negative loops restricting emergent outcomes. An exclusive focus on top-down measures 
may have a negative impact by not taking into account local knowledge and the system dynamics associated with resilience. Moreover, identifying successful practices at the community level opens the possibility for replication or facilitation in other contexts. At the initial stage of the pandemic, the aggregate products of interlocking behavior were employment creation, money circulation, access to health services, and an infection rate that was substantially lower than the rate of the city of São Paulo. However, the reduction in donations and other external resources led to an increase in mortality and infection rates. In such cases, public health measures could benefit by identifying and supporting the emergent practices that proved successful at the local level. Unfortunately, this does not seem to be the case in the context of a selecting environment characterized by uncoordinated state policies and even conflicting governmental discourses in Brazil.

The contribution of the present article in relation to previous studies in community resilience [25-29] is the further articulation of a conceptual framework deriving from the study of socio-ecological systems and the identification of cultural milieu factors related to community resilience. The importance of social ties and network of interaction is highlighted in Meyer and Aldrich [29]. However, conceptualizing networks' emergence as characteristics of a complex adaptive system provided the opportunity to explore feedback loops and the emergence of new patterns of behavior in response to environmental crises. Both the behavioral analytic metacontingency framework and systems analysis go beyond the effect of policies on the individual; the analytical focus is on the emergence of new patterns of behavior and innovation as aggregate products. The novelty of the present study in relation to previous behavioral studies during the COVID-19 pandemic is the consideration of a complex systems perspective and the analysis of resilience processes, bridging the gap with a behavior analytic framework of cultural phenomena.

This study contributes to the investigation of community self-organizing responses to the pandemic as previously described by Fransen et al. [30]. It further highlights the importance of local knowledge and pre-existing organizational capacity [30]. However, the novelty of the present study lies in the application of an evolutionary conceptual framework highlighting the temporal dynamics of learning, adaptation and maintenance of innovative practices. Previous studies on community resilience in the context of the COVID-19 pandemic described adaptation to the crisis, but not learning and implications for future challenges. This single case analysis highlights the continuum of past experience and the emergence of new patterns of behavior as multiple possible equilibria points.

\section{Conclusions}

Governments' policies in response to the COVID-19 crisis have varied from highly restrictive social distancing measures, closing most public spaces, to rather flexible ones. However, from the complex systems perspective, it is also important to consider the decentralized emergence of communities' practices in response to the pandemic. The main contribution of this present article consists of bringing a behavioral perspective to community resilience as a system capability. By applying the concept of cultural milieu to explore self-organizing responses in a complex system, the mosaic of contextual variables and selecting factors related to community resilience was described. Worldwide, different public health measures have aimed to contain the spread of the virus and thereby control the pandemic. At the policy-making level, there is the assumption that controlling the pandemic and a return to a sense of normality can be achieved [61]. However, striving for normal at all costs may restrain the capacity to learn, innovate, and be prepared for the next environmental disturbances. In the case of socially vulnerable communities, such as Paraisópolis, the question seems to be not so much the return to a previous normality, but the opportunity of renewal and the aggregated production of better living standards. The case described here shows that the community exhibits an important element of system resilience and that successful emergent practices can be recognized and even nurtured at the policy level. 
Author Contributions: Conceptualization, F.B. and K.C.C.; methodology, F.B. and K.C.C.; software, F.B.; formal analysis, F.B and K.C.C.; investigation, F.B.; writing-original draft preparation, F.B and K.C.C.; writing-review and editing, F.B. and K.C.C.; All authors have read and agreed to the published version of the manuscript.

Funding: This research received no external funding.

Institutional Review Board Statement: The study was conducted according to the guidelines of the Declaration of Helsinki, and approved by the Norwegian Centre for Research Data. Project Reference: 538979 .

Informed Consent Statement: Informed consent was obtained from all subjects involved in the study.

Data Availability Statement: Due to privacy reasons and confidentiality, the data are not publicly available. Queries about data availability may be directed to the corresponding author.

Acknowledgments: We thank Flora Lorenzo for constructive comments and suggestions during the final writing process.

Conflicts of Interest: The authors declare no conflict of interest.

\section{Appendix A. Interview Guide}

Operationalizing categories from Folke [18] (p. 259):

- Characteristics: Interplay disturbance and reorganization, sustaining and developing;

1. When was the moment that you became aware that the pandemic would reach Paraisópolis?

2. What kind of previous organizations facilitated new practices?

- Focus: Adaptive capacity, transformability, learning and innovation;

3. What have you learned during the pandemic?

4. How were the different strategies towards that containing the pandemic created?

5. How was movement of the street presidents created? How is your experience with this movement?

- Context: Integrated systems feedback and cross-scale dynamic feedback.

6. How are results monitored?

7. How is the communication between street presidents and the residents' association?

8. What challenges do you identify at this point?

9. From your experience, what may be kept maintained from this period after the pandemic?

10. Is there anything you would to like to add?

\section{References}

1. Cohen, J.; Kupferschmidt, K. Countries test tactics in 'war' against COVID-19. Science 2020, 367, 1287-1888. [CrossRef] [PubMed]

2. Axelrod, R.; Cohen, M.D. Harnessing Complexity; Basic Books: New York, NY, USA, 2000.

3. Corburn, J.; Vlahov, D.; Mberu, B.; Riley, L.; Caiaffa, W.T.; Rashid, S.F.; Ko, A.; Patel, S.; Jukur, S.; Martinez-Herrera, E.; et al. Slum health: Arresting COVID-19 and improving well-being in urban informal settlements. J. Urban Health 2020, 97, 1-10. [CrossRef] [PubMed]

4. Scott, J.C. Seeing Like a State: How Certain Schemes to Improve the Human Condition Have Failed; Yale University Press: New Haven, CT, USA, 1998.

5. Mamelund, S.-E. Social inequality_A forgotten factor in pandemic influenza preparedness. Tidsskr. Den Nor. Legeforening 2017, 137, 911-913. [CrossRef] [PubMed]

6. Tampe, T. Potential impacts of COVID-19 in urban slums: Addressing challenges to protect the world's most vulnerable. Cities Health 2020. [CrossRef]

7. Lopes, M. Brazil's Favelas, Neglected by the Government, Organize Their Own Coronavirus Fight. Available online: https:/ / www.washingtonpost.com/world/the_americas/coronavirus-brazil-favela-sao-paulo-rio-janeiro-bolsonaro/2020/0 6/09/8b03eee0-aa74-11ea-9063-e69bd6520940_story.html (accessed on 10 July 2020). 
8. Instituto Pólis. Paraisópolis Tem Melhor Controle da Pandemia do que o Município de São Paulo. Available online: https: //agenciagalo.com/wp-content/uploads/2020/06/Release-P\%C3\%B3lis-Parais\%C3\%B3polis.pdf (accessed on 10 August 2020).

9. Instituto Pólis. Mortes Por Covid-19 Crescem 240\% em Paraisópolis em Dois Meses. Available online: https://www.capitolio.com. br/noticias/2020/09/08/mortes-por-covid-19-em-paraisopolis-crescem-240-em-dois-meses/ (accessed on 10 October 2020).

10. Malott, M.; Glenn, S. Targets of intervention in cultural and behavioral change. Behav. Soc. Issues 2019, 15, 31-57. [CrossRef]

11. Borba, A. The selection of different interlocked behavioral contingencies and maintenance of common pool resources: The case of the production of açaí berries. Behav. Soc. Issues 2019, 28, 229-247. [CrossRef]

12. Couto, K.; Lorenzo, F.; Tagliabue, M.; Henriques, M.; Lemos, R. Underlying principles of a Covid-19 behavioral vaccine for sustainable cultural change. Int. J. Env. Res. Public Health 2020, 17, 9066. [CrossRef] [PubMed]

13. Van Bavel, J.; Baicker, K.; Boggio, P.; Capraro, V.; Cichoka, A.; Cikara, M.; Crockett, M.; Crum, A.; Douglas, K.; Druckman, J.; et al. Using social and behavioral science to support Covid-19 pandemic response. Nat. Hum. Behav. 2020, 4, 460-471. [CrossRef] [PubMed]

14. Tibério, S.; Mizael, T.; Luiz, F.; Rocha, C.; Araújo, S.; dos Santos, A.; Terhoch, G.; Guarnieri, L.; Fonseca Júnior, A.; Hunziker, M. A natureza comportamental da pandemia de Covid-19. Rev. Bras. Análise Comp. 2020, 16, 57-70. [CrossRef]

15. Camargo, J.; Calixto, F. Combatendo a tragégia dos comuns: Como estratégias para autocontrole de cooperação social podem contribuir para o enfrentamento da pandemia de Covid-19. Rev. Bras. Análise Comp. 2020, 16, 71-83.

16. Amorim, V.C.; Guimarães, T.M.M.; de Almeida, J.A.T.; Vanderlon, Y.; \& Abdala, M. Promoção de isolamento social na pandemia de covid-19: Considerações de análise comportamental da cultural. Rev. Bras. Análise Comp. 2020, 16, 31-40. [CrossRef]

17. Carpenter, S.; Walker, B.; Anderies, J.M.; Abel, N. From metaphor to measurement: Resilience of what to what? Ecosystems 2001, 4, 765-781. [CrossRef]

18. Folke, C. Resilience: The emergence of a perspective for social-ecological systems analyses. Glob. Environ. Chang. 2006, 16, 253-267. [CrossRef]

19. Holland, J.H. Hidden Order How Adaptation Builds Complexity; Addison-Wesley: Reading, PA, USA, 1995.

20. Houmanfar, R.; Rodrigues, N.J.; Ward, T.A. Emergence and metacontingency: Points of contact and departure. Behav. Soc. Issues 2010, 19, 53-78. [CrossRef]

21. Sandaker, I. A selectionist perspective on systemic and behavioral change in organizations. J. Organ. Behav. Manag. 2009, 29, 276-293. [CrossRef]

22. Sánchez, J.G.A.; Houmanfar, R.A.; Alavosius, M.P. A Descriptive Analysis of the Effects of Weather Disasters on Community Resilience. Behav. Soc. Issues 2019, 28, 298-315. [CrossRef]

23. Kaliou, M.; van de Lindt, J.; McAllister, T.; Ellingwood, B.; Dillard, M.; Cutler, H. State of the research in community resilience: Progress and challenges. Sustain. Resilient Infrastruct. 2018, 5, 131-151. [CrossRef]

24. Nguyen, H.; Akerkar, R. Modelling, measuring and visualizing community resilience: A systematic review. Sustainability 2020, 12, 7896. [CrossRef]

25. Cohen, O.; Leykin, D.; Lahad, M.; Goldberg, A.; Aharonson-Daniel, L. The conjoint of community resilience assessment measure as a baseline for profiling and predicting community resilience for emergencies. Technol. Forecast. Soc. Chang. 2013, 80, $1732-1741$. [CrossRef]

26. Cohen, O.; Goldberg, A.; Lahad, M.; Aharonson-Daniel, L. Building resilience: The relationship between information provided by municipal authorities during emergency situations and community resilience. Technol. Forecast. Soc. Chang. 2017, 121, 119-125. [CrossRef]

27. Pfefferbaum, B.; Pfefferbaum, R.; Van Horn, R. Community resilience interventions: Participatory, assessment-based, actionoriented processes. Am. Behav. Sci. 2015, 59, 238-253. [CrossRef]

28. Houston, J. Boucing forward: Assessing advances in community resilience assessment, intervention, and theory to guide future work. Am. Behav. Sci. 2015, 59, 175-180. [CrossRef]

29. Aldrich, D.; Meyer, M. Social capital and community resilience. Am. Behav. Sci. 2015, 59, 254-269. [CrossRef]

30. Fransen, J.; Peralta, D.; Vanelli, F.; Edelenbos, J.; Olvera, B. The emergence of community resilience initiative during the Covid-19 pandemic: An international exploratory study. Eur. J. Dev. Res. 2020, 1-23. [CrossRef]

31. Xu, W.; Xiang, L.; Proverbs, D.; Xiong, S. The influence of Covid-19 on community resilience. Int. J. Environ. Res. Public Health 2021, 18, 88. [CrossRef] [PubMed]

32. Holland, J.H. Complex adaptive systems. Daedalus 1992, 121, 17-30.

33. Skinner, B.F. Operant behavior. Am. Psychol. 1963, 18, 503-515. [CrossRef]

34. Ferster, C.B.; Skinner, B.F. Schedules of reinforcement. Am. J. Psychol. 1959, 72, 320. [CrossRef]

35. Glenn, S.S. Metacontingencies in walden two. Behav. Anal. Soc. Action 1986, 5, 2-8. [CrossRef]

36. Krispin, J. Positive feedback loops of metacontingencies: A new conceptualization of cultural-level selection. Behav. Soc. Issues 1997, 26, 95-110. [CrossRef]

37. Folke, C.; Carpenter, S.R.; Walker, B.; Scheffer, M.; Chapin, T.; Rockström, J. Resilience thinking: Integrating resilience, adaptability, and transformability. Ecol. Soc. 2010, 15, 20. [CrossRef]

38. Wan, K.M.; Ho, L.K.K.; Wong, N.W.; Chiu, A. Fighting COVID-19 in Hong Kong: The effects of community and social mobilization. World Dev. 2020, 134, 105055. [CrossRef] [PubMed] 
39. Rowling, M. COVID-19: How Past Crises are Helping the World's Cities to Respond and Rebuild. Available online: https: //www.weforum.org/agenda/2020/05/cities-pandemic-coronavirus-covid19-health-response-response-rebuild/ (accessed on 10 July 2020).

40. Holling, C.S. Resilience and stability of ecological systems. Annu. Rev. Ecol. Syst. 1973, 4, 1-23. [CrossRef]

41. Berkes, F. Environmental governance for the Anthropocene? Social-ecological systems, resilience, and collaborative learning. Sustainability 2017, 9, 1232. [CrossRef]

42. Olsson, P.; Folke, C.; Berkes, F. Adaptive comanagement for building resilience in social-ecological systems. Environ. Manag. 2004, 34, 75-90. [CrossRef]

43. Folke, C.; Hahn, T.; Olsson, P.; Norberg, J. Adaptive governance of social-ecological systems. Ann. Rev. Environ. Resour. 2005, 30, 441-473. [CrossRef]

44. Peters, D.P.; Bestelmeyer, B.T.; Turner, M.G. Cross-scale interactions and changing pattern-process relationships: Consequences for system dynamics. Ecosystems 2007, 10, 790-796. [CrossRef]

45. Levin, S.A. Ecosystems and the biosphere as complex adaptive systems. Ecosystems 1998, 1, 431-436. [CrossRef]

46. Heylighen, F. The science of self-organization and adaptivity. Encycl. Life Sup. Syst. 2001, 5, 253-280.

47. Duchek, S. Organizational resilience: A capability-based conceptualization. Bus. Res. 2020, 13, 215-246. [CrossRef]

48. Kantor, J.R. Cultural Psychology, 1st ed.; Principia Press: Chicago, IL, USA, 1982.

49. Center for Systems Science and Engineering-Johns Hopkins University. Coronavirus Resource Center. Available online: https: / / coronavirus.jhu.edu/map.html (accessed on 30 November 2020).

50. IBGE. Grade Estatística e o Atlas Digital Brasil 1 Por 1. Available online: https://www.ibge.gov.br/geociencias/atlas/tematicos/ 24684-atlas-digital-brasil-1-por-1.html?=\&t=downloads (accessed on 25 October 2020).

51. Vieira, T. Paraisópolis. Available online: https://www.tucavieira.com.br/paraisopolis (accessed on 20 October 2020).

52. Rede Nossa São Paulo. Mapa da Desigualdade 2019. Available online: https:/ /www.nossasaopaulo.org.br/2019/11/05/mapada-desigualdade-2019-e-lancado-em-sao-paulo/ (accessed on 1 October 2020).

53. Ajzenman, N.; Cavalcanti, T.; Da Mata, D. More than words: Leaders' speech and risky behavior during a pandemic. Soc. Sci. Res. Netw. 2020, 3582908. [CrossRef]

54. Roubaud, F.; Razafindrakoto, M.; Saboia, J.; Castilho, M.; Pero, V. The Municipios Facing COVID-19 in Brazil: Socioeconomic Vulnerabilities, Transmisssion Mechanisms and Public Policies (No. DT/2020/12). Available online: https://www.ie.ufrj.br/ images/IE/TDS/2020/TD_IE_032_2020_ROUBAUD_et\%20al.pdf (accessed on 20 November 2020).

55. Cruz, C.H.D.B. Social distancing in São Paulo State: Demonstrating the reduction in cases using time series analysis of deaths due to COVID-19. Rev. Bras. Epidemiol. 2020, 23, e200056. [CrossRef] [PubMed]

56. State of São Paulo. Adesão ao Isolamento Social em São Paulo. Available online: https://www.saopaulo.sp.gov.br/coronavirus/ isolamento/ (accessed on 20 November 2020).

57. Merriam, S. Introduction to qualitative research. In Qualitative Research in Practice. Examples for Discussion and Analysis, 1st ed.; Merriam, S.B., Ed.; Jossey-Bass: San Francisco, CA, USA, 2002; pp. 3-17.

58. de Carvalho, L.C.; Sandaker, I.; Ree, G. An ethnographic study of tagging cultures. Behav. Soc. Issues 2017, 26, 67-94. [CrossRef]

59. Tsoukas, H.; Hatch, M.J. Complex thinking, complex practice: The case for a narrative approach to organizational complexity. Hum. Relat. 2001, 54, 979-1013. [CrossRef]

60. Gibbs, G.R. Qualitative Data Analysis: Explorations with NVivo, 1st ed.; Open University: Philadelphia, PA, USA, 2002.

61. Norman, J.; Bar-Yam, Y.; Taleb, N.N. Systemic Risk of Pandemic via Novel Pathogens—Coronavirus: A Note. New England Complex Systems Institute. Available online: https://necsi.edu/systemic-risk-of-pandemic-via-novel-pathogens-coronavirus-anote (accessed on 7 December 2020). 